\title{
Familiáris, aránytalan sinuscsomó-tachycardia
}

\author{
Borbola József, Somogyi Anikó
}

\author{
Gottsegen György Országos Kardiológiai Intézet, Felnőtt Kardiológiai Osztály, Elektrofiziológiai és Pacemaker \\ Terápiás Osztály, Budapest \\ Levelezési cím: \\ Dr. Borbola József \\ 1096 Budapest, Haller utca 29. E-mail: borbola@kardio.hu
}

Célkitűzés: A familiáris, inadekvát, aránytalan sinuscsomó-tachycardiával kapcsolatosan világszerte kevés információ áll rendelkezésre. Célunk ezen betegek kivizsgálásával és kezelésével szerzett saját tapasztalataink ismertetése.

Betegek és módszerek: Az elmúlt tíz évben aránytalan sinuscsomó-tachycardiás 104 beteg közül négy esetben (3,8\%) észleltük családi halmozódás előfordulását (apa [57 éves] és lánya [29 éves], valamint két testvér [fiú: 22 éves, lány: 20 éves]). Mindegyiküknél laboratóriumi vizsgálat, 12 elvezetéses EKG, mellkasröntgen, szívultrahang, Holter-monitoros megfigyelés, terheléses EKG, valamint transztelefonikus EKG-vizsgálatok történtek.

Eredmények: Strukturális szívbetegsége egyiküknek sem volt (mellkasröntgen, EKG, szívultrahang-vizsgálatok), laboratóriumi leletek is normálisnak bizonyultak (Hgb: $146 \pm 11 \mathrm{~g} / \mathrm{l}$, TSH: 2,12 $\pm 0,40 \mu \mathrm{mol} / \mathrm{l}$ ). A betegcsoport nyugalmi sinusfrekvenciája $117 \pm 10 / \mathrm{min}$ volt az EKG-vizsgálatkor. Holteren a napi átlagos sinusfrekvencia magas volt (95 $\pm 6 / \mathrm{min}), 54 \pm 4 / \mathrm{min}$, illetve $175 \pm 12 /$ min szélső értékekkel. A transztelefonikus EKG a panaszok alatt mindig sinus tachycardiás epizódokat rögzített. A bisoprolol $(2 \times 5 \mathrm{mg} / \mathrm{nap})$ (Holter: $79 \pm 9 / \mathrm{min}(p<0,05)$, szélsőértékek: $54 \pm 5 / \mathrm{min}$, illetve $132 \pm 16 / \mathrm{min}(p<0,005)$ és az ivabradin ( $2 \times 5 \mathrm{mg} / \mathrm{nap})$ is (Holter: $79 \pm 3 / \mathrm{min} p<0,03$, szélső értékek: $50 \pm 1 / \mathrm{min}$, illetve $148 \pm 8 / \mathrm{min}(p<0,05)$ javította a Holter-monitoros paramétereket, valamint a betegek panaszait (EHRA tüneti skála: kontroll: $2,4 \pm 0,5$, kezelés alatt: $1,0 \pm 0(p<0,005)$ egyaránt.

Megbeszélés: A familiáris aránytalan sinuscsomó-tachycardia ritka klinikai szindróma, a szokásosnál is magasabb sinus tachycardia hajlammal. Mind a béta-blokkoló, mind pedig az $\mathrm{I}_{\mathrm{f}}$-csatorna-gátló kezelés hatékonynak bizonyult. Az újabb irodalmi adatok alapján a nomotop szívritmuszavar hátterében a HCN4-csatorna fehérje (R524Q) génmutációja merült fel.

Kulcsszavak: aránytalan sinuscsomó-tachycardia, familiaritás, bisoprolol, ivabradin

\section{Familiar, inappropriate sinus node tachycardia}

Aims: The worldwide information with familiar, inadequate, inappropriate sinus node tachycardia is limited. Our aim was to publish of our own experiences with the medical examinations and drug therapy of these patients.

Patients and methods: In the last ten years from 104 patients we noticed 4 patients (3.8\%) with the accumulation of inappropriate sinus-node tachycardia [father (57 years old), daughter (29 years old); and a brother (22 years old) and sister (20 years old)]. All patients underwent 12 leads ECG, chest X-ray, echo, laboratory investigation, Holter-monitoring and transtelephonic ECG observations.

Results: Patients had no structural heart disease. Laboratory values (Hgb: $146 \pm 11 \mathrm{~g} / \mathrm{l} ; \mathrm{TSH}: 2.12 \pm 0.40 \mu \mathrm{mol} / \mathrm{l})$ were within normal values. The resting heart rate of the patient group was $117 \pm 10 / \mathrm{min}$ on the ECG. The results of Holter recording (expressed as minimal-maximal and (average) heart-rate/min) without drug therapy showed high heart rate values: $59 \pm 8 /$ $\min -160 \pm 14-(94 \pm 6 / \mathrm{min})$. During the patients symptoms the transtelephonic ECG showed episodes of sinus tachycardias in each patients. The bisoprolol $(2 \times 5 \mathrm{mg} /$ day) therapy (Holter: $54 \pm 5 / \mathrm{min}-132 \pm 16 / \mathrm{min}(p<0.05)-(79 \pm 9 / \mathrm{min}(p<0.05)$ and the ivabradine treatment $(2 \times 5 \mathrm{mg} /$ day) (Holter: $50 \pm 1 / \mathrm{min}-148 \pm 8 / \mathrm{min}(p<0.05)-79 \pm 3 / \mathrm{min})$ as well improved not only the Holter-parameters, but also the patient's symptoms (EHRA score control: $2.4 \pm 0.5$, during treatment $1.0 \pm 0(p<0.005)$.

Conclusion: The familiar inappropriate sinus node tachycardia is a rare clinical syndrome with a propensity for higher rates of sinus tachycardias. Both of the beta-blocking drug bisoprolol and the If channel blocker ivabradine proved to be useful for treatment. In the background of this nomotope cardiac arrhythmia the gene mutation of the HCN4 channel protein (R524Q) was suggested.

Keywords: familiar, inappropriate sinus node tachycardia, familiarity, bisoprolol, ivabradine 


\section{Bevezetés}

1941-ben közölte elsőként Wising (1) az inadekvát, aránytalan sinuscsomó-tachycardia (IST) kongenitális előfordulását. A sino-atriális (SA-) csomó pacemaker-sejtjeiben a spontán diasztolés depolarizáció meredekségét, a sinusfrekvenciát döntően egy befelé irányuló, transzmembrán vegyes ionáram (Na/K), az ún. I („f-funny”) csatorna működése szabályozza. Az $\mathrm{I}_{\mathrm{f}}$-csatorna, amelyet pacemaker-áramnak is neveznek, a HCN-(hiperpolarizáció aktivált, ciklikus nukleotidkapuzott) csatornák családjába tartozik. Négy változata, izoformja létezik (HCN 1-4), amelyek közül az 1-es és a 4-es van jelen a humán SA-csomóban, de a pacemaker-sejtek müködését döntően a 4-es izoform szabályozza. Az SA-csomó adrenerg (cAMP) és kolinerg (muscarin-receptorok - 2R) szabályozása is az $\mathrm{I}_{\mathrm{f}}$ pacemaker-áram direkt befolyásolásával történik $(2,3,4)$. Nemrégen (2017) kiderült, hogy az $\mathrm{I}_{\mathrm{f}}$-csatorna HCN4 összekötő alegységének (R524Q) „gain of function” mutációja jelentős sinus tachycardiát tud előidézni. Ez a génmutatáció ugyanis fokozza az $\mathrm{I}_{\mathrm{f}}$-csatorna cAMP iránti érzékenységét, így permanens sinus tachycardiát idéz elő (15). Ezt az eltérést összefüggésbe hozták az ún. familiáris IST megjelenésével (6).

Jelen közleményünk célja az IST hazai familiáris elöfordulásával kapcsolatos saját eseteink, tapasztalataink ismertetése. Korábbi hasonló közlést a hazai orvosi szakirodalomban nem találtunk.

\section{Betegek és módszerek}

A Gottsegen György Országos Kardiológiai Intézet egyik felnőtt járóbeteg-rendelésén 2008-2018 között 104 IST-s beteget (92 nő, 12 férfi; átlagos életkor: $31 \pm 10$ [16-57]) diagnosztizáltunk. A betegcsoport átlagos testsúlya, illetve testmagassága $64 \pm 12 \mathrm{~kg}$, illetve $165 \pm 6 \mathrm{~cm}$ volt. A betegcsoport fö tünetei a gyakori, időszakos, egyenletesen gyors szívverésérzés, palpitáció (100\%), gyengeség, fáradékonyság, csökkent terhelhetőség $(68 \%)$ és a mellkasi diszkomfort, mellkasi szúrásérzés (38\%) panaszai voltak. A palpitációs panaszok átlagosan 24£29 (1-120) hónapja álltak fenn. $A z$ életminőséget jellemző EHRA (European Heart Rhythm Association) tüneti skálán a betegcsoport jel-

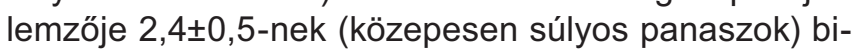
zonyult.

Az IST diagnózisára Morillo és munkatársai (7), Olshansky és munkatársai (8), valamint az ACC/AHA/ESC

(9) által javasolt kritériumokat használtuk:

1. nyugalmi aránytalan sinus tachycardia ( $\geq 100 / \mathrm{min})$,

2. a 12 elvezetéses EKG-n a P-hullám morfológiája, tengelyállása az SA-csomóból kiinduló tachycardiára utal,

3. a 24 órás Holter-monitoros megfigyelésen a napi átlag sinusfrekvencia $\geq 90 / \mathrm{min}$,
4. szekunder kardiális vagy extrakardiális ok kizárható, 5. a panasz alatt az SA-csomó frekvenciaemelkedés fokozatos, nem paroxizmális, a sinus tachycardia megszúnése is fokozatos,

6. ektópiás jobb pitvari tachycardia vagy SA-csomó reentry tachycardia kizárható. Az IST diagnosztikájával kapcsolatosan utalunk korábbi közleményünkre is (4).

A 104 IST-s beteg közül familiaritás, családi halmozódás 4 személynél $(3,8 \%)$ derült ki (apa [57 éves] és leánya [29 éves] valamint két testvér [fiú: 22 éves, leány: 20 éves]) eseteiben. Mindegyik betegnél fizikális, majd 5 perc pihenés után 12 elvezetéses EKG (MAC 1200 ST, USA) vizsgálatot végeztünk. Mindenkinél laboratóriumi vizsgálat is történt az extrakardiális, szekunder okok kizárása céljából. A kivizsgálás kardiovaszkuláris gyógyszermentes periódusban történt. A PSVT-k kiszürésére 3-4 hetes (indokolt esetben hosszabb) transztelefonikus EKG-megfigyelést (IMS Heart View P12/8 Plus, Aerotel), valamint 24 órás Holter-monitorozást (Innomed Medical Argusys FD) végeztünk. Utóbbi a napi szívfrekvencia-tartomány és a panaszok alatti ritmuszavarok megfigyelésére szolgált. A fizikai terhelés által kiváltott sinusfrekvencia-növekedés, PSVT kiválthatóság, terhelhetőség megállapítása céljából standard terheléses EKG-vizsgálat (Innomed Medical ergometer, módosított Bruce-protokoll) is történt. A strukturális szívbetegség megállapítására/kizárására mellkasröntgent, rutin echokardiográfiát végeztünk.

Vizsgálati eredményeink statisztikai analízise a Student t-teszt alkalmazásával történt. Minden esetben az átlagértékek mellett az átlag standard deviációját ( $\pm S D$ ) adtuk meg. A p<0,05 értékeket tekintettük statisztikailag szignifikánsnak.

\section{Eredmények}

A családi halmozódást mutató IST-s betegeknek (két család 2-2 tagja: 2 nő, 2 férfi; átlagéletkor: 32ะ18 [2057 ) év]) átlagosan $15 \pm 4$ éves koruk óta voltak az életminőségüket befolyásoló, a betegek által közepesen súlyosnak értékelt (EHRA tüneti skála: $2,4 \pm 0,5$ ) palpitációs panaszai. Szekunder ok mindegyiküknél ki-

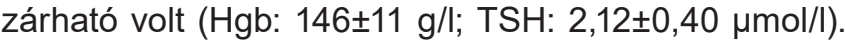
Strukturális szívbetegség sem igazolódott, a bal kamra szisztolés funkciója is épnek, normálisnak (66 $610 \%)$ bizonyult. A betegcsoport nyugalmi EKG-ján a sinuscsomó frekvenciája magas volt: $117 \pm 10 / \mathrm{min}$. A familiaritást mutató alatt IST-s család leánytagjának jellegzetes 12 elvezetéses EKG-felvétele az 1. ábrán látható. A családi halmozódást mutató első és második IST-s család elérhető családfáját, a 2. illetve a 3. ábrán tüntettük fel. A betegcsoport gyógyszermentes időszakban elvégzett 24 órás Holter-monitoros megfigyelése során az átlagos, napi sinusfrekvencia magas volt: $95 \pm 6 / \mathrm{min}$, $56 \pm 4 / \mathrm{min}$, illetve $175 \pm 12 / \mathrm{min}$ szélső értékekkel. A nap- 


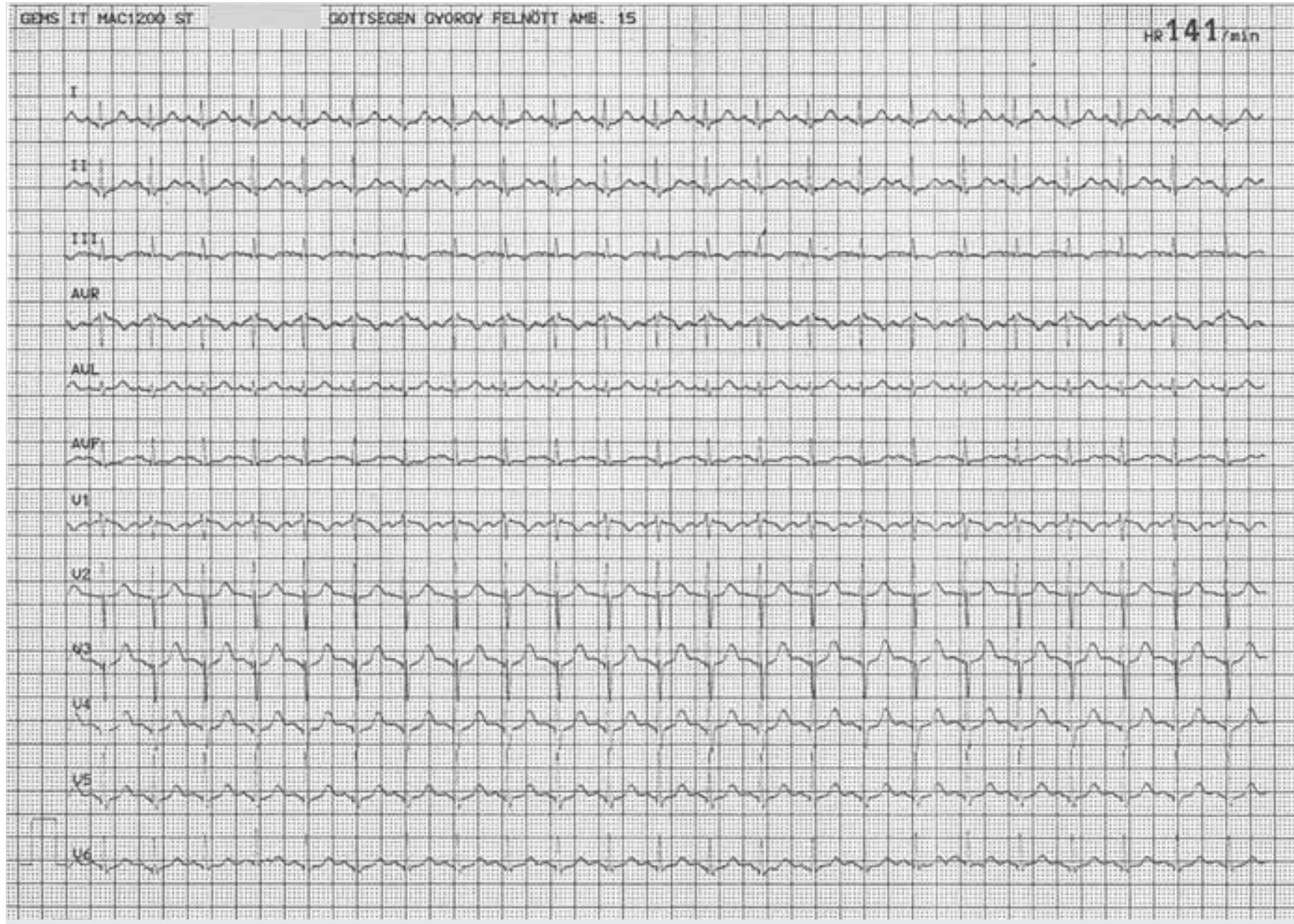

1. ÁBRA. A familiaritást mutató első IST-s család érintett nőtagjának jellegzetes sinus tachycardiás 12 elvezetéses EKG-képe (141/min sinus tachycardia normális PQ-, QT-távolságok, inkomplett JTSZB)

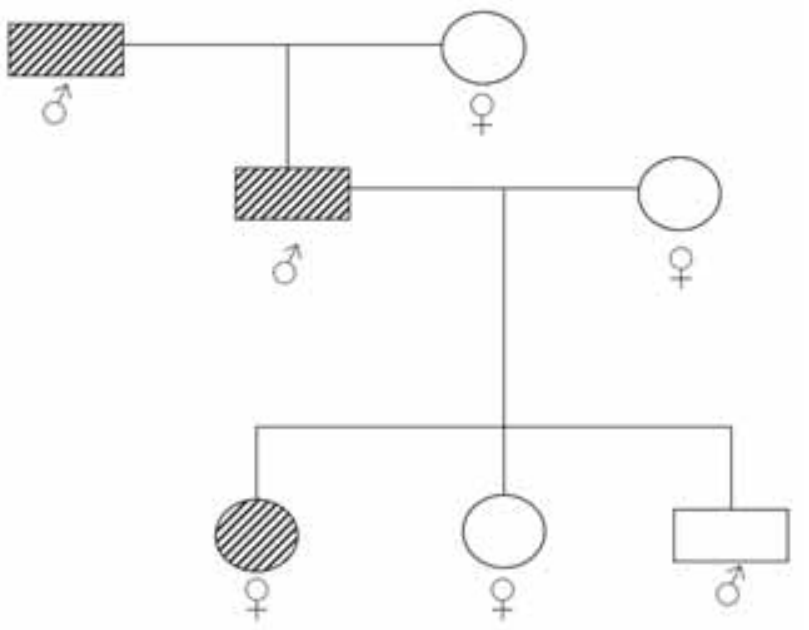

2. ÁBRA. A familiárisan érintett első IST-s család elérhető családfája. (A nagyapának mindig gyors szívverése volt. Az édesapa 18 éves korában észlelte először gyors pulzusát. Az érintett egyik lánya 10 éves korában tapasztalta elöször gyorsabb szívverését, a másik két testvér szívverése normális. Az apa 56 évesen, a leánya 32 évesen került először észlelésre. $\square$ : familiárisan érintett családtagok

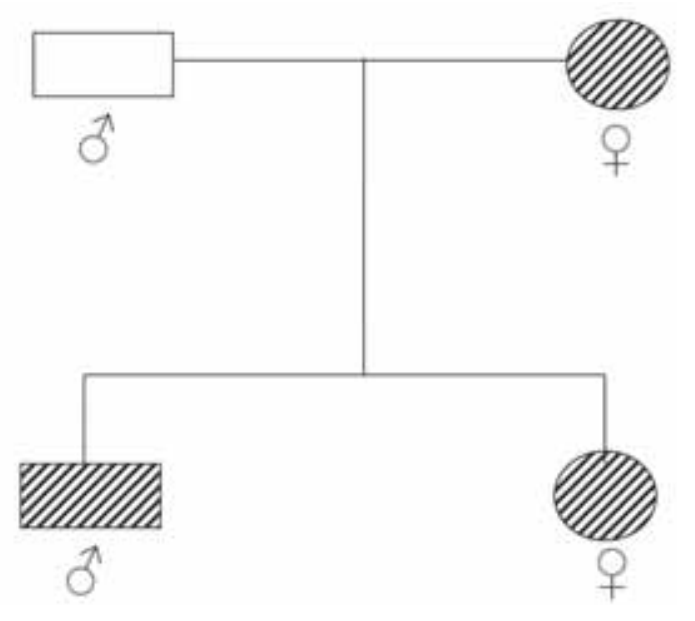

3. ÁBRA. A familiárisan érintett második IST-s család testvérpárjának elérhető családfája. (Az édesanyának mindig is gyors szívverése volt. A testvérpár 17-18 évesen észlelte, hogy a terhelésnél hamarabb kifulladnak, a szívverésüket gyakran egyenletesen gyorsnak találták.)

$\square$ :familiárisan érintett családtagok 


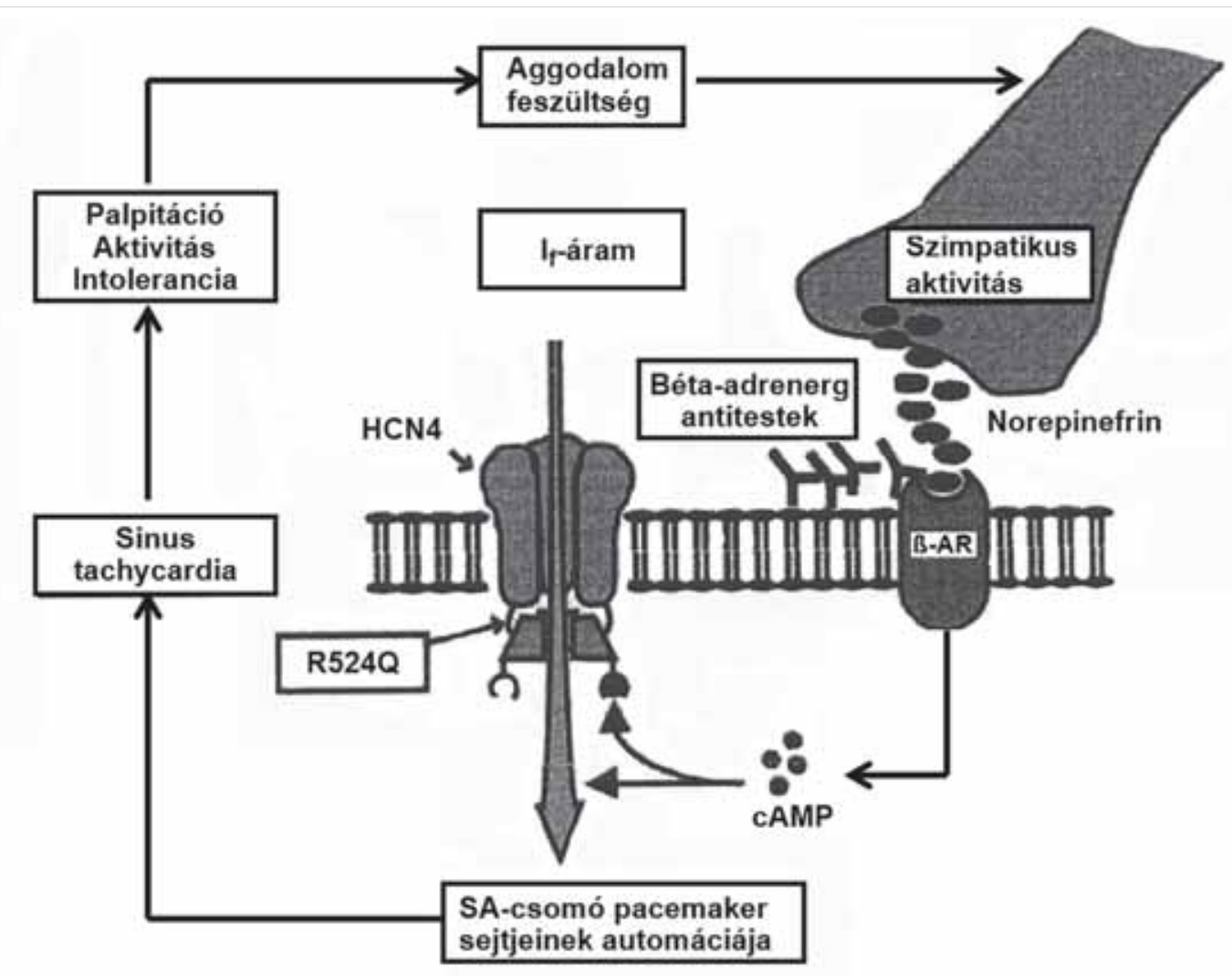

4. ÁBRA. A HCN4 szerepe az aránytalan sinuscsomó-tachycardia patomechanizmusában. A HCN4 C-linker fehérje R524Q mutációja fokozza a HCN4 izoform érzékenységét a cAMP-vel szemben. Az ábra szintén feltünteti a sinuscsomó fokozott automáciájához, tachycardizálódáshoz vezető más tényezőket is (szimpatikus aktivitásfokozódás, anti-béta-adrenerg antitestek aktiválódása, aggodalom, belső feszültség), amelyek hatásai szinergitikusak lehetnek

pali időszakban különösen délelőtt, kora délután és estefelé palpitációs panaszt, szédülést okozó, fokozatosan kialakuló és megszűnő sinus tachycardiás epizódokat észleltünk. A terheléses EKG-vizsgálat kapcsán jó terhelhetőség mellett szintén magas nyugalmi sinusfrekvenciát $(112,0 \pm 14,8 / \mathrm{min})$ tapasztaltunk. A terhelés során igen gyors tachycardizálódást észleltünk a terhelés csúcspontján 165,5 $\pm 2,0 /$ min sinus tachycardiával. A vérnyomás mindenkinél az életkorának és a terhelhetőségének megfelelően, normálisan emelkedett, a terhelés más szívritmuszavart senkinél nem provokált.

A panaszok alatti EKG rögzítése, elemzése, illetve az esetleges más szívritmuszavarok jelentkezése, megfigyelése miatt mindegyik betegnél 3-4 hetes transztelefonikus EKG-vizsgálat is történt. Mindegyik betegnél a panaszok alatt mindig gyors sinus tachycardiás epizódokat tapasztaltunk, PSVT vagy paroxizmális pitvarfibrilláció egyik betegnél sem fordult elő.

A betegcsoport panaszainak a kezelésére az életmód-modifikáció (vagotonizáló gyakorlatok, jóga, enyhe sport stb.) mellett elsőként béta-blokkolót (bisoprolol $2 \times 5 \mathrm{mg} / \mathrm{nap}$ ), majd megbeszélés, hozzájárulás után "off label" ivabradin $(2 \times 5 \mathrm{mg} / \mathrm{nap})$ terápiát alkalmaztunk. Mind a béta-blokkoló kezelés (Holter: $54 \pm 5 /$ min -
132 $\pm 16 /$ min $[p<0,005]$ szélsőértékek, sinusfrekvencia, illetve $79 \pm 9 / \mathrm{min}$ [ $p<0,05]$, átlagfrekvencia, mind pedig az ivabradin terápia [Holter: $50 \pm 1-148 \pm 8 / \mathrm{min}$ ] [ $<0,03$ ] szélsőértékek, sinusfrekvencia, illetve 79,0 $\pm 3,4 / \mathrm{min}$ [p<0,03] átlagfrekvencia]) is sokat javított nemcsak a palpitációs panaszokon (EHRA score: 1,0 $\pm 0, p<0,005$ ), hanem a Holter-monitoros paramétereken is. A kisszámú familiáris IST-s betegen úgy tűnik, a béta-blokkoló kezelés jobban csökkentette a napi maximális sinusfrekvenciát, mint a hasonló adagú ivabradin terápia. Az ivabradin kezelés ugyanakkor jobban csökkentette a nyugalmi sinusfrekvenciát, mint a bisoprolol terápia. Statisztikai különbséget a két eltérő hatású gyógyszercsoport között azonban ebben a hasonló napi dózisban nem tudtunk igazolni.

Az első IST-s családnál a béta-blokkoló okozta mellékhatások (álmosság, bágyadtság, alacsonyabb vérnyomásértékek) miatt az ivabradin kezelés vált be jobban. $A z$ apa és az érintett leánya is mintegy tíz éve ezt a gyógyszert szedi, intoleranciát, mellékhatást, problémát nem tapasztaltunk. (Az érintett leány gyermeket szülni már nem kívánt.)

A második IST-s család fiatalabb testvérpárja béta-blokkolót szed jelenleg is, amely javította terhelhetöségüket, mellékhatásról, panaszról nem számoltak be. 


\section{Megbeszélés}

Az IST klinikai szindrómájával mindennap, egyre gyakrabban találkozhatunk a kardiológiai/aritmológiai szakrendeléseken $(10,11)$. A betegcsoport nem homogén: a szimpatovagalis egyensúlyzavarral küszködő betegek mellett a posztablációs betegcsoport után a legkisebb csoportot $(3,4 \%$-ot) a familiárisan érintett IST-s betegek képezik $(8,12,13)$. Megfigyeléseink szerint ezekre az IST-s egyénekre a következők a jellemzők:

1. családi érintettség apai vagy anyai ágon;

2. primer, $\geq 100 /$ min sinus tachycardia hajlam már a korai életkorban (10-20 év között);

3. a 24 órás Holter-monitoros megfigyelésen a szokásosnál is magasabb, napi átlagos sinusfrekvencia értékek;

4. terheléses EKG-vizsgálatkor a terhelés előtti magas nyugalmi pulzusszám után terhelésre hirtelen, gyorsan emelkedő, inadekvát sinustachycardia;

5. mind az $\mathrm{I}_{\mathrm{f}}$-csatorna-gátló ivabradin, mind pedig a béta-blokkoló bisoprolol hatékony a panaszok csökkentésére (EHRA tüneti skála a kezelések mellett: $1,0 \pm 0,0 ; p<0,005)$. A családoknál genetikai vizsgálat még nem történt.

A tízéves utánkövetés során gyógyszeres kezelés mellett tachycardiomyopathia kialakulását nem tapasztaltuk. A szelektív $\mathrm{I}_{\mathrm{f}}$-csatorna-inhibitor gyógyszer, az ivabradin minden esetben hatékony volt. Az alkalmazott adagban, más bradycardizáló gyógyszert együtt nem használva, mellékhatást, intoleranciát nem észleltünk (14-17).

A familiáris IST hátterében számos kiváltó ok már régóta felmerült: a sinuscsomó pacemaker-sejtjeinek fokozott aktivitása/érzékenysége, fokozott szimpatikus szenzitivitás, csökkent vagalis tónus mellett aktiválódó anti-bétaadrenerg antitestek, fokozott belső aggodalom, pszichés feszültség is felmerült. Ezek elméletileg szinergisták is lehetnek. Legutóbb ebben a ritka betegcsoportban az R524Q-aminosav cseréjét írták le a HCN4 csatornafehérje C-linker kapcsolódásnál (4. ábra). Ez az eltérés fokozza a HCN4-csatorna fehérje érzékenységét a cAMP hatásával szemben. Ennek ellentétjéröl is beszámoltak, amely viszont „idiopátiás” sinus bradycardiát okoz $(5,6,16)$.

A familiáris IST patomechanizmusának további felde- rítése, megértése hozzásegíthet ezen régóta ismert nomotop szívritmuszavar különböző típusainak pontosabb kezeléséhez is.

\section{Irodalom}

1. Wising P. Familiar, congenital sinus tachycardia. Acta Med Scand 1941; 108: 299-305

2. Difrancesco D. Characterization of single pacemaker channels in cardiac sino-atrial node cells. Nature 1986; 324: 470-473.

3. Nagy $\mathrm{N}$, Varró A, Tóth $\mathrm{A}$. A sinuscsomó spontán automáciájának mechanizmusa: egy két évtizedes vita krónikája. Card Hung 2017; 47: G96-G102. doi: 10.26430/CHUNGARICA.2017.47.suG.96

4. Borbola J. Az aránytalan sinus tachycardia. Card Hung 2010; 40: 144-151

5. Vedantham V, Scheinman MM. Familiar inappropriate sinus tachycardia: a new chapter in the story of HCN4 channelopathies. Eur Heart J 2017; 38: 289-291. doi: 10.1093/eurheartj/ehv635

6. Baruscotti M, Bianco E, Bucchi A, et al. Current understanding of the pathophysiological mechanisms responsible for inappropriate sinus tachycardia: role of the If "funny" current. J Interv Card Electrophysiol 2016; 6: 19-28. doi: 10.1007/s10840-015-0097-y

7. Morillo CA, Klein GJ, Thakur RK, et al. Mechanism of inappropriate sinus tachycardia. Role of sympathovagal balance. Circulation 1994; 90: 873-877.

8. Olshansky B, Sullivan RM. Inappropriate sinus tachycardia. JACC 2013; 61: 793-801. doi: 101016/jacc.2012.07.074

9. Page RL, Joglar JA, Caldwell MA, et al. 2015 ACC/AHA/HRS Guideline for the management of adult patients with supraventricular tachycardia. JACC 2016; 67: e27-e115.

10. Bauerfeind RA, Leon AZ Dhingra RC, et al. Chronic nonparoxysmal sinus tachycardia in otherwise healthy persons. Ann Int Med 1979; 91: 702-710.

11. Still A-M, Raatikainen P, Ylitalo A, et al. Prevalence, characteristics and natural course of inappropriate sinus tachycardia. Europace 2005; 7: 104-112.

12. Peyrol M, Lévy S. Clinical presentation of inappropriate sinus tachycardia and differential diagnosis. J Interv Card Electrophysiol 2016; 46: 33-41. doi: 10.1007/s10840-015-0051-z

13. Borbola J. Inadekvát, aránytalan sinuscsomó-tachycardia: egy régi szívritmuszavar új megvilágításban. Orv Hetil 2019 (közlés alatt) 14. Borbola J. Successful treatment of inappropriate sinus tachycardia with ivabradine. Eur Heart J 2009; 30(Suppl): 566.

15. Scheinmann MM, Vedantham V. Ivabradine a ray of hope for inappropriate sinus tachycardia. JACC 2012; 60: 1330-1332.

16. Oliphant CS, Owens RE, Bolorunduro OB. Ivabradine a review of labelled and off-label uses. Am J Cardiovasc Drugs 2016; 16: 337-347. doi: 10.1007/s40256-016-0178-z

17. Baruscoti M, Bucchi A, Milanesi R, et al. A gain-of-funtion mutation in the cardiac pacemaker HCN4 channel increasing CAMP sensitivity is associated with familiar inappropriate sinus tachycardia. Eur Heart J 2017; 38: 280-288. doi:10.1093/eurheartj/ehv582 